Helgoländer wiss. Meeresunters. 24, 247-255 (1973)

\title{
Vertical distribution and cellular heat resistance of bottom animals from the Possyet Bay (Japan Sea)
}

\author{
A. V. ZHIRMUNSKY \\ Laboratory of Physiological Ecology, Institute of Marine Biology, \\ Far-Eastern Scientific Center, Academy of Sciences; Vladivostok, USSR
}

KURZFASSUNG: Vertikalverbreitung und zelluläre Hitzeresistenz von Bodentieren aus der Possjet-Bucht (Japanisches Meer). Die vertikale Zonierung verschiedener benthonischer Tiere, die in halbgeschlossenen Buchten des Japanischen Meeres untersucht wurden, weicht von den im gleichen Gebiet an Inseln und Steilabhängen festgestellten Tiefenverbreitungen $a b$. Diese Unterschiede können von der Art des Substrats, der Gezeitenwirkung, den Strömungsverhältnissen und insbesondere von den Temperaturbedingungen abhängen. Ein experimenteller Vergleich der zellulären Hitzeresistenz von Cilienepithelien verschiedener Muschel- und AscidienArten und deren Vertikalverbreitung konnte vor allem den Einfluß der Temperatur deutlich machen. Es wird die Schlußfolgerung gezogen, daß artspezifische Anpassungen an die Umgebungstemperatur, die offensichtlich auf Unterschieden in der Proteinstruktur beruhen, die Vertikalverbreitung von Bodentieren entscheidend mitbestimmen.

\section{INTRODUCTION}

The phenomenon of vertical zonality, i. e. regular change of community composition during the transition from coastal sea sites to deeper horizons was established early last century in works by AUdouin \& MiLne-EDWARds (1832), Forbes (1846) and others. A large amount of literature has been devoted to this problem, including a series of surveys (Gislen 1930, Ekman 1953, Zenkevich 1951, and others). Nevertheless, only the intertidal zone has been studied comparatively well. In the majority of the USSR seas, however, for the upper sublittoral (from 0 to $30-40 \mathrm{~m}$ ) there is insufficient knowledge of the bottom communities, the population density and biomass of species which comprise them, and their vertical distribution and ecology.

However, the first investigations carried out with the use of diving techniques in areas previously studied only by conventional, old methods have made it possible to discover some new species in the fauna and to make essential corrections to our understanding of communities inhabiting these areas and their distribution (Propr 1962,

* In contrast to the French (Peres 1966), for designation of the vertical zones we use the terminology adopted by the majority of the Soviet investigators and also authors writing in English. "Littoral" comprises the intertidal zone; sublittoral is the zone from 0 depth to 150-200 m; upper sublittoral, from 0 to $30 \mathrm{~m}$. 
1971, Zhirmunsky 1963, Scarlato et al. 1964, Golikov \& Scarlato 1967a, b, and others).

The investigations have shown that the vertical distribution of the same species differs in different latitudes and even in different sites of the same water body, and that it depends upon the effect of a number of environmental factors. Under the influence of temperature changes, rubbing intertidal ice, water currents, absence of suitable substratum, predation and so on, vertical displacements of individual species and of communities take place. In some regions the distributional limits move down to deeper areas, in others they rise to the upper horizons.

Analyzing the literature and our own data concerning the vertical distribution of the bottom molluses in the White Sea (ZHIRmunsky 1969), we came to the conclusion that the vertical zonation is more pronounced when there is a more or less uniform gradient in temperature decrease with depth. Such a situation exists in the main gutter of the White Sea. In sea areas with strong tidal flows, the surface water and the water of deeper layers mix and have very similar temperatures.

Analogous phenomena can be seen in Peter the Great Bay. Propp \& Budin (1969) and BuDIN (1971) showed that the vertical distribution of a number of species (sea-star Patiria pectinifera, sea-urchins Strongylocentrotus nudus and S. intermedius, and molluscs Crenomytilus grayanus, Swiftopecten swifi, Mizuhopecten yessoensis) near the islands and capes of Peter the Great Bay is only slightly affected by depth and to a considerable extent depends upon substratum, the degree of mobility, and the action of predators. These studies were made in depths down to $30-40 \mathrm{~m}$, and the temperature difference between these depths and the surface was not more than $2.5^{\circ} \mathrm{C}$.

In order to reveal vertical zonation, therefore, one must look to the semi-enclosed bays which, in summer, show distinct temperature stratification. Our studies (ZHTRMUNSKY 1967, 1969) and investigations by Golikov \& SCARLato $(1967 \mathrm{a}, \mathrm{b})$ have shown that the semi-enclosed bay in the Possyet and Vostok Bays possess this quality.

In the present paper, the results of investigations obtained on vertical distribution of some mass species of the bottom animals living in the upper sublittoral of the Possyet Bay are presented in dependence on temperature conditions, substratum and animal mobility. These data are compared with cell heat resistance (thermostability), which may be used as species characteristic (UsHakov 1959), reflecting the temperature conditions to which the species was adapted during the process of micro-evolution.

\section{METHODS}

In order to study the vertical distribution, aqualungs were used. The limits of the vertical distribution of the species inhabiting the Possyet Bay were established and also the zone in which the species is abundant (ZHIRMunskx 1963, 1967, 1969). These data were supplemented by results obtained by the hydrobiological expedition of the Zoological Institute of the USSR Academy of Sciences (Golrkov \& SCARLATo $1967 a, b)$.

Heat resistance of the ciliated epithelium was estimated according to the retention time of ciliary movement ("survival time") in preparations placed in sea water heated 
to a definite constant temperature. According to the mean data obtained from 6 to 10 experiments for four different temperatures, semi-logarithmic curves were constructed of time dependence of the temperature-dependent loss of functional activity. Each curve is based on results with preparations obtained from $20-40$ specimens of a given species.

The degree of cellular heat resistance is expressed as the straight lines within the limits of the injurious temperatures. Comparing their position or the temperatures which lead to cessation of cilia movement at a definite time, one can assess differences in cellular heat resistance of the species studied. A similar method was used by SCHLIEper et al. (1960). Characteristics of the species studied are given in Table 1.

\section{RESULTS}

Possyet Bay includes some half-enclosed bays where distinct temperature stratification occurs subsequent to summer heating of the upper water layers. The water temperature at the surface and in $20 \mathrm{~m}$ depth may differ as much as $5^{\circ}-6^{\circ} \mathrm{C}$ (Golmov \& SCARLATo 1967a). In August, sea-water temperature reaches about $21^{\circ}-23^{\circ} \mathrm{C}$ at the surface and in shallow-water bays up to $25^{\circ}-27^{\circ} \mathrm{C}$. This thermal regime appears to be the main condition which enables the coexistence in close proximity of subtropical and boreal species.

Table 1 presents data on the vertical distribution of 15 species of bottom animals inhabiting mostly solid substrates, and belonging to 4 classes - bivalves, gastropods, sea-stars and ascidians. As can be seen from the Table, the vertical distribution of the species studied varies considerably. Thus the mainly subtropical species Crassostrea gigas, Rapana thomasiana, Mytilus coruscus, Ceratostoma burnetti, Patiria pectinifera, and Arca boucardi occur in the uppermost horizons of the sublittoral. The low boreal Chlamys nipponensis, Crenomytilus grayanus, Halocynthia roretzi, Asterias amurensis, Modiolus difficilis, Mizubopecten yessoensis, Swiftopecten swifti and the widely distributed species Musculus laevigatus and Halocyntbia aurantium inhabit deeper zones.

The comparison of the vertical zones in which species are abundant is quite significant. Simultaneously, they are characteristic of the communities inhabiting the various depths (Golikov \& SCARLATo 1967a).

In Table 1 species are arranged in the order of decreasing cellular heat resistance. This fact enables us to compare the degree of cellular heat resistance with the vertical distribution of the species and to evaluate the relationship of the characteristics mentioned. Species 1-3 exhibit the highest degree of cellular heat resistance and mainly occupy the uppermost sublittoral from 0 to $2 \mathrm{~m}$. In contrast, species with the lowest cellular heat resistance (12-15) live in deeper sea zones.

A more detailed consideration of the data presented in Table 1 reveals that some species do not fit into the general pattern, because of their wide distribution over the whole spectrum or a considerable part of the depths studied. These are species which actively move about on the sea bottom, such as gastropods, sea-stars and jumping scallops. If we exclude them from the consideration and compare the primary vertical 


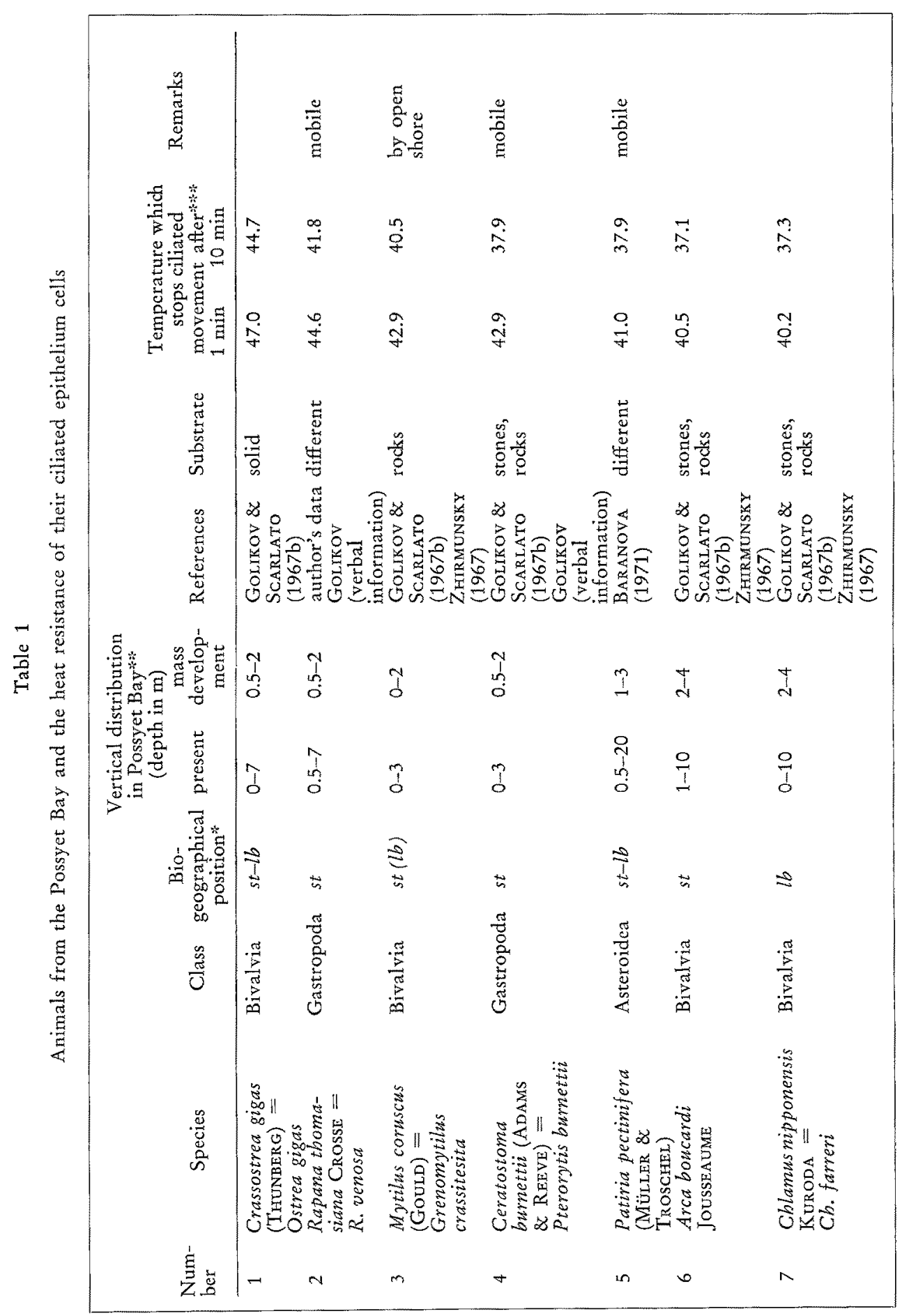


Vertical distribution and heat resistance

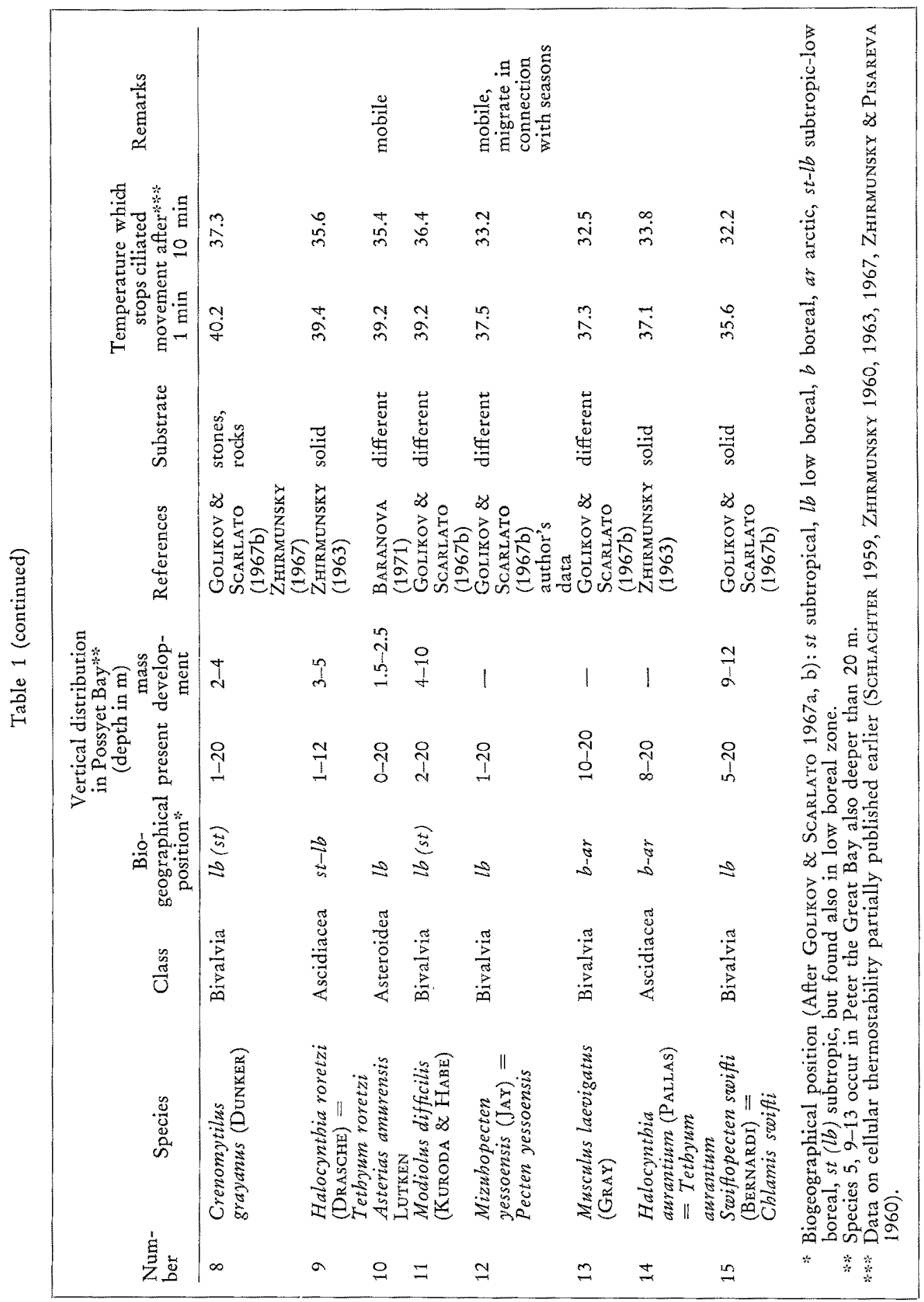


distribution of non-mobile forms, bivalves and ascidians, a more distinct pattern becomes evident (Fig. 1).

Thus regularities in vertical distributions of species, as related to temperature adaptations, are expressed more clearly in non-mobile species and to a lesser degree in species moving about actively in search of food; this situation is analogous to that described by ANDRIJASHEV (1939) with regard to latitudinal distributions of bottom fishes.

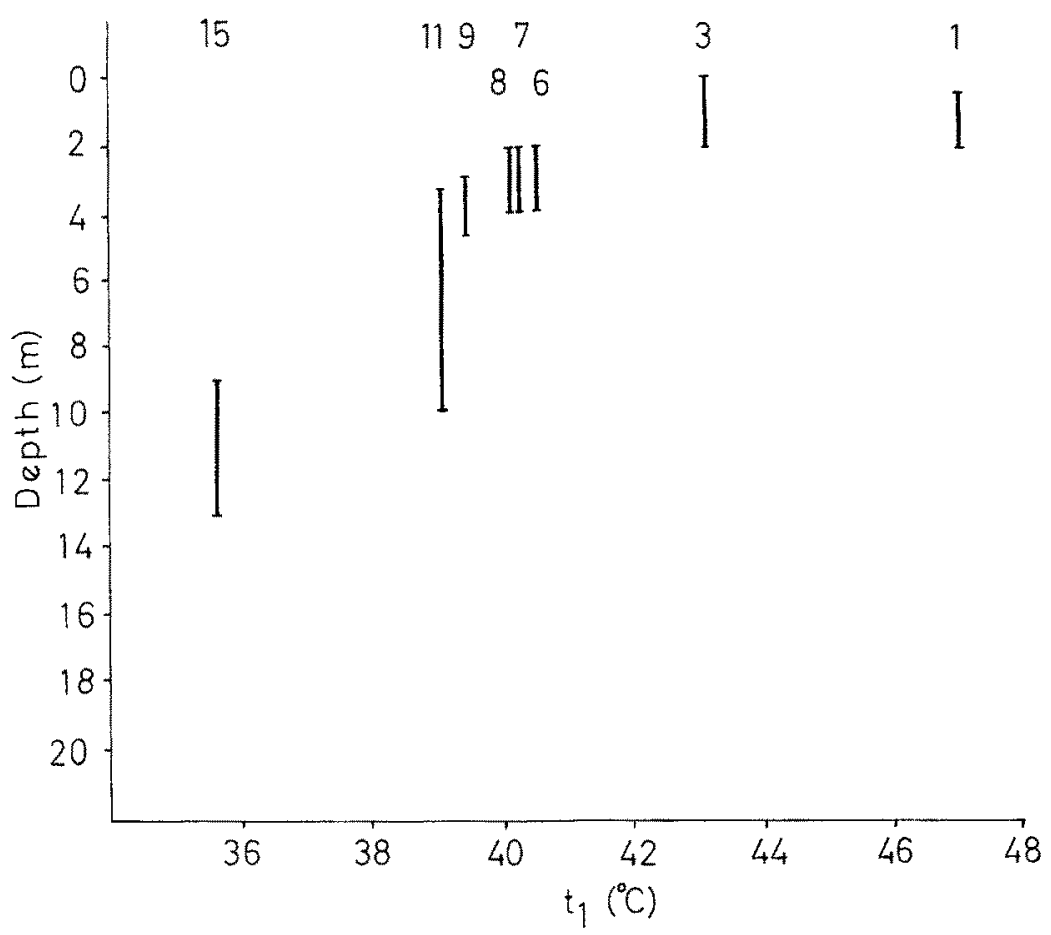

Fig. 1: Cellular heat resistance, $t\left(^{\circ} \mathrm{C}\right.$ ), of the ciliated epithelium in bivalves and ascidians in relation to the depths of their mass development in Possyet Bay (Japan Sea). Vertical lines indicate the main vertical distribution of the species; numbers designate the species listed in Table 1

Analogous relationships can be seen when comparing taxonomically closely related species, for example, the ascidians Halocyntbia roretzi and $H$. aurantium (ZHIRMUNSKY 1963). Our observations show that $H$. roretzi occurs below $1 \mathrm{~m}$ depth in rocky bays of the Possyet Bay. The greatest number of $H$. roretzi was recorded at $3-5 \mathrm{~m}$; the number then decreases; in general, $H$. roretzi does not occur below $12 \mathrm{~m}$ depth. We have found that $H$. aurantium occurs below $8 \mathrm{~m}$ and, according to REDIKORTSEV (1941), it has been recorded from depths down to $180 \mathrm{~m}$. The cellular thermostability curves of these species are presented in Figure 2. As seen from this figure, the cellular thermostability of $H$. roretzi, which inhabits the uppermost part of the sublittoral, is higher than that of $H$, aurantium which lives in deeper waters. 
The same data were obtained for two mytilids - Mytilus coruscus, which occurs in the Possyet Bay from 0 to $3 \mathrm{~m}$, and Crenomytilus grayanus (from 1 to $20 \mathrm{~m}$ ) (Fig. 3 ).

Our studies revealed regular differences in vertical distributions of some species inhabiting the upper sublittoral of the Possyet Bay, and demonstrated relationships between the vertical distributions of species and the heat resistance of their cells.

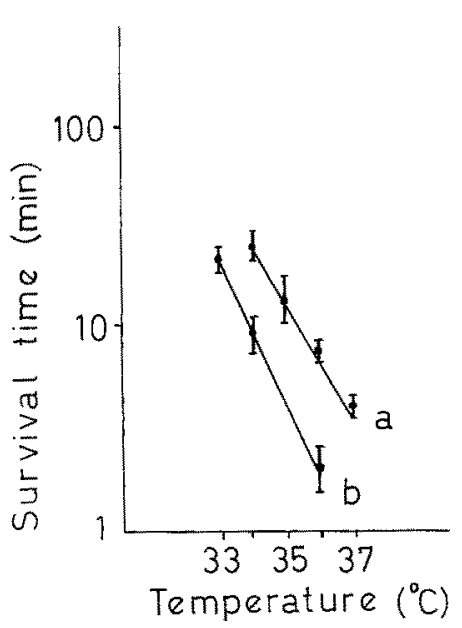

Fig. 2: Cellular survival time of the ciliated epithelium in ascidians Halocyntbia roretzi (a) and $H$, aurantbium (b) as a function of temperature

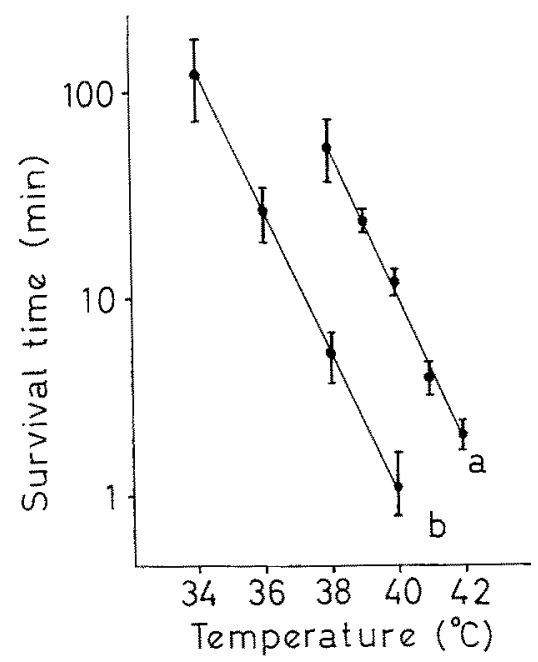

Fig. 3: Cellular survival time of the ciliated epithelium in bivalves Mytilus coruscus (a) and Crenomytilus grayanus (b) as a function of temperature

\section{CONCLUSIONS}

The combined in situ and laboratory investigation presented here comprises part of a study conducted to analyse the interrelationships between the latitudinal and vertical distributions of bottom animals and their thermal adaptations (ZHIRMUNSKY 1960-1969).

According to the protein theory of the cell injuries suggested by the Russian cytophysiologists Nassonov \& Alexandrov (1940), the basis of cell reactions to different injuries lies in the denaturation of cell proteins. From this viewpoint, the differences in cellular heat resistance are comparable to the results of cell protein differences. This was confirmed by establishing the amino-acid protein composition of identical cells in closely related species (TARTAKOVSKY et al. 1960).

\section{SUMMARY}

1. Investigations on 15 mass species of bottom animals (Bivalvia, Gastropoda, Asteroidea, Ascidia), performed by means of aqualungs in semi-enclosed bays of the 
Possyet Bay (Peter the Great Bay of the Japan Sea), have revealed a clear zonality in their vertical distribution. This finding is in contrast to the situation found near islands and capes of Peter the Great Bay, where species distributions are weakly connected with depth, but to a considerable degree determined by the nature of substrate, degree of tides and presence of predators.

2. These differences may be explained by differences in summer temperature conditions, considerable decrease of the temperature gradient with increase of depth in semi-enclosed bays, insignificant surface temperature differences and, in depths of about $20-30 \mathrm{~m}$, by intensive water mixing near islands and capes.

3. Comparison of the vertical distribution of species from the Possyet Bay with their cellular heat resistance (species-specific feature, used for characterizing genetic heat adaptation) reveals conformity between these indices.

4. These results and literature data suggest that the differences in vertical distribution of the bottom invertebrates living in coastal waters are the result of the speciesspecific adaptation of their cells to environmental temperature; differences in protein structure of different animals are considered to provide the basis of this phenomenon.

Acknowledgements. I wish to express my cordial thanks to Dr. O. KrNNE, due to whom this paper is published here and who kindly discussed it with me.

\section{LITERATURE CITED}

Andruashev, A. P., 1939. Zoogeographic essay and origin of fish fauna in the Bering Sea and adjacent waters (Russ.). Leningrad.

Audourn, J. V. \& Mrlane-Edwards, H., 1832. Recherches pour servir a l'histoire naturalle du littoral la France. I. Paris.

Baranova, Z. I., 1971. Echinoderms from the Possyet Bay of the Japan Sea (Russ.). In: Fauna i flora zaliva Possyeta Japonskogo morja. Nauka Press, Leningrad, 242-264.

Bumn, I. N., 1971. Distribution of some bottom invertebrates in coastal waters of Peter the Great Bay. (Russ.) Nauch. Sobshch. Inst. Biol. Morja 2, 34-37.

EKMAN, S., 1953. Zoogeography of the sea. Sidgwick \& Jadkson, London.

Forses, E., 1846. On the connection between the distribution of the existing fauna and flora of the British Isles and the geological changes which have affected this area. Mem. Geol. Surv. U.K. 1, 336-432.

GrsLen, T., 1930. Epibioses of the Gullmar Fjord. P. 2 Marine sociology (Kristinebergs Zoologiska Station, 1877-1927.) Skr Ser. K. svenska Vetensk Akad. 1930 (4), 1-380.

Golixov, A. N. \& Scarlato, O. A., 1967a. Ecology of bottom biocoenoses in the Possyet Bay. Helgoländer wiss. Meeresunters. 15, 193-201.

- 1967b. Mollusks of the Possyet Bay and their ecology (Russ.). In: Molluski $\mathrm{i}$ ih rol $\mathrm{v}$ biocenozah i formirovanii faun. Nauka Press, Leningrad, 5-154.

Nasonov, D. N. \& Alexandrov, B. Y., 1940. Reaction of the living matter on the external action (Russ.). Akademija Nauk Press Moskva-Leningrad.

Peres, J. M., 1966. La vie dans l'Océan. Paris.

PROPP, M. V., 1962. Some results of study of the Eastern Murman sublittoral in Dalnie Zelentsi area by means of aqualungs. (Russ.) In: Trudy murmansk. morsk. biol. Inst. 4 (8), $59-63$.

- 1971. Ecology of the coastal bottom communities of the Murmansk coast of the Barents Sea. (Russ.). Nauka Press, Leningrad. 
- \& Budin, I. N., 1969. Distribution of the mass species of the bottom invertebrates in coast of the Putjatin. Island of the Japan Sea. (Russ.) Ref. nauch. Rab. Inst. Biol. Morja, Vladivostok 1, 135-138.

REDikorTSEV, V. V., 1941. Ascidias of the USSR Far-Eastern Seas. (Russ.) In: Issled. dalnevost. Morei SSSR 1, 164-215.

Scarlato, O. A., Golmov, A. N. \& Gruzov, E. N., 1964. Diving method of the hydrobiological studies. (Russ.) Okeanologija 4, 707-719.

SCHLACHTER, T. A., 1959. Comparative study of the cellular thermostability of the ciliated epithelium in some species of the sea stars. (Russ.) Cytologiya 1, 369-373.

SCHLIEPER, C., Flügel, H. \& RudolF, J., 1960. Temperature and salinity relationships in marine bottom invertebrates. Experientia 16, 470-477.

Tartakovsky, A. D., Pashkova, A. M., Pinaev, G. P., Zhirmunsky, A. V. \& Vorobjev, V. I., 1960. Aminoacid composition of myosin in two close related species of frogs. (Russ.) Cytologiya 2, 506-508.

Ushakov, B. P., 1959. Tissue thermostability as one of the diagnostic specific features in poikilothermic animals. (Russ.) Zool. Zh. 38, 1292-1302.

ZeNKEVICH, L. A., 1951. Fauna and biological productivity of the sea. I: World Ocean. (Russ.) Akademija Nauk Press, Moskva.

Zhirmunskx, A. V., 1960. Studies of the temperature adaptations in invertebrates of the South-China Sea. (Russ.) Cytologija 2, 675-691.

- 1963. Cellular thermostability of the ciliated epithelium in two species of the single ascidias of the genus Tethyum in relation to environmental temperature. (Russ.) Cytologija 5, 227-230.

- 1967. A comparative study of cellular thermostability of marine invertebrates in relation to their geographical distribution and ecology. In: The cell and environmental temperature. Engl. ed. C. L. Prosser (Russ. ed.: A. S. Troshin). Pergamon Press, Oxford, 209-218.

- 1969. A comparative study of cellular thermostability in mollusks of the White Sea in relation to the vertical distribution of species and history of fauna formation. (Russ.) Zh. Obshch. Biol. 30, 685-702.

- \& Pisareva, L. N., 1960. Tissue thermostability of some marine animals living in different depths. (Russ.) Vop. cytol. protistol., 112-116.

\author{
Author's address: Dr. A. ZHIRMunsKy \\ Laboratory of Physiological Ecology \\ Institute of Marine Biology \\ Far-Eastern Scientific Center \\ Academy of Sciences \\ Vladivostok 690022 \\ USSR
}

